\title{
2. Ministers as Ministries and the Logic of their Collective Action
}

\author{
John Wanna
}

As recounted in the opening chapter, ministerial responsibility is primarily understood and studied as a formal accountability process with the emphasis largely on individual ministerial accountability and the occasional resignation. This preoccupation with individual responsibility reflects a British obsession with the behaviour of the particular minister (Dowding and Kang 1998; Woodhouse 1994) or a scepticism of the observance of collective responsibility, especially when governments disintegrate - the so-called 'myth/fallacy' argument (see Dell 1980; Weller 1985). There is generally less attention paid to the dimensions of collective ministerial responsibility and the politics of maintaining cohesion, other than the seminal acknowledgment by constitutionalists of the need for cabinet solidarity in modern parliamentary government (Crisp 1973, 353; Dicey 1885; Jennings 1959), and the incantation of the political requirement in modernday ministerial codes (see Australian Government, Cabinet Handbook, 2009, ss. 15-24). Collective ministerial responsibility is arguably a far less formal form of accountability, interpreted largely by the prime minister, and exercised through political expedience, some malleable conventions and frequent reinterpretation. Moreover, collective responsibility is defined and given expression not only in the (positive) requirements for collegial solidarity, but also in the degree of latitude shown to dissention and to breaches of the principles.

As will be explored below, ministers are political actors who are simultaneously individual and collective entities. They play out these dual but overlapping roles across a range of interactions in which they more or less engage. These interactions occur with their contemporaries at the centre of government (around cabinet and its political, symbolic and decision-making processes), in their relations with senior officials and their departments, with the public service and media and with the wider community. But, importantly, they are also played out in two other critical contexts that impact on their behaviour: first, in the context of the collaborative/competitive incentive frames they inhabit and negotiate with their fellow party colleagues; and second, against their political opponents or other opposing interests.

This chapter focuses on ministers acting as a ministry, as a collegial entity, expressing their 'collective responsibility'. It examines their logics of collective action-not in the narrow Olsonian sense of the 'free rider' problem, but in the sense of the compelling logic of mutual obligations and reciprocal 
responsibilities. Hence, the focus is on the degree of solidarity they invest with each other and especially on the role of the prime minister and other senior ministers in imposing collective conventions over the group.

Analytically, there are both external and internal dimensions to this collective endeavour. The external dimensions are where cohesion is usually a symbolic or tactical device - for instance, at ceremonial functions representing the nation, in their phalange-like behaviour in parliament, their relations with the media and interactions with lobby groups and constituents. The internal dimensions include the minister's personal relations with the prime minister, political support for the leader, the operational dynamics of cabinet and the wider ministry, factional dynamics and the degree of party support for themselves (or others) as ministers. These two dimensions constitute forms of political accountability (largely to themselves as a group) for the ministerial collective: outward accountability (accountability to the parliament, nation, the media); and inward accountability to cabinet and the party room. Senior ministers (and especially the leader) are accountable in both dimensions simultaneously and constantly. Each dimension can serve to enhance or erode the standing of the ministry depending on how ministers behave, are perceived to be performing and maintain their collegial support structures.

In Australia, there is relatively little literature on cabinet dynamics over the term(s) of the government or the operational collectivities of ministries, including the exercise of collective responsibility. A very thin literature exists, which tends to depict Australia as an essentially utilitarian and majoritarian polity, within which the individual responsibility of ministers has been to their own party rather than to parliament (see Encel 1962). Some constitutionalists have then gone on to reinterpret Australian practice as a political system where collective responsibility became the dominant constitutional convention (over individual responsibility) while acknowledging that this was contingent upon time and circumstance (see Finn 1990). There is even less literature on the formation of cabinets either from a qualitative (how they are formed, composed, who manages to become appointed, how coalitions are crafted) or quantitative interpretation (though see Michael Dalvean's controversial Chapter 3 in the current volume). This latter phenomenon is perhaps best explained by acknowledging that traditionally there have been few researchers who have chosen to focus on this topic, and because Australian cabinets are usually monological (single-party majoritarian governments known ahead of the election and not indeterminate multi-party coalitions negotiated in the wake of electoral outcomes). ${ }^{1}$ The exceptions in the Australian literature are Sol Encel

1 The Liberal-National coalition is a standing arrangement traditionally based on a mutual recognition of territory (seats) and a non-competitive electoral stance; it is sometimes referred to as a 'coalescence' arrangement (see Sartori 1976) and is not the equivalent of party coalitions in European polities where various 
(1962) who provided an earlier account of executive government; also the collected works of Patrick Weller (for example, 1985, 1989, 1990, 2007) who has both chronicled and explained the dynamics of the Fraser, Hawke and Howard cabinets; the ruminations of Neal Blewett $(1999,2006)$, a former academic and federal politician who recounts the machinations of the Hawke and Keating cabinets constantly searching for the epicentre of power; and Glyn Davis (1992) who mischievously treated the internal dynamics of cabinet as metaphorically akin to American 'street gangs' (paralleling the sociological works of Frederick Thrasher in The Gang and William Foote Whyte in Street Corner Society), organised by power and esteem, reputation, internal bargains, implicit deals and constant renegotiations of influence. ${ }^{2}$

\section{Ministries as Both a Collegial and a Rivalling Team: The interplay of competitive and collaborative motivations and incentives}

Australian ministries are invariably composites of professional politicians - they are composed of elected, full-time politicians, constituency-based representatives (or regional senators) and almost entirely party-aligned apparatchiks who owe their primary loyalty to their party and factional support base. These career politicians display various motivational and behavioural qualities that coexist simultaneously but may be either pronounced or latent, including: loyalties, alliances, rivalries, personal ambition, envy, jealousy or hatred, subterfuge or deception. The precise mix of these qualities on display is highly contingent depending on circumstance or exercised by political intuition and astuteness. Ministries, thus, are composed of ambitious and competitive individuals who also generally wish to convey the impression of forming a unified, collective entity of some sort. How this collective actually coheres may be sui generis and discrete to specific governments or prime ministers (compare the Whitlam and Hawke ministries, or those of Fraser and Howard, Rudd or Julia Gillard; see Weller 2007).

Ministers are appointed constitutionally and formally by the head of state (on advice from the prime minister) usually to fulfil dedicated portfolio or functional

party combinations can be formed after each election. Moreover, the coalition arrangements between the Liberal Party and The Nationals are only significant in some jurisdictions federally, in New South Wales, Victoria and Western Australia; they are not a feature in Tasmania, South Australia, the Northern Territory, the Australian Capital Territory, or now in Queensland where the two parties have formally merged.

2 There are occasional chapters in textbooks that throw light on cabinet dynamics (but usually as a clearinghouse or policymaking vehicle), and occasional presentations by some of the key participants (see Codd 1990 and more generally the collection by Galligan et al. 1990). Mostly these practitioner reports merely chart current practice. 
responsibilities. Importantly, they are appointed as individuals to their official posts - as ministers with a given title, an area of portfolio responsibility and a specific set of authorisations (often contained in statutes). They are, thus, appointed to and held responsible for specific sets of duties, compartmentalised functions, bodies of legislation and assigned organisations (departments and agencies). These ministers expect a degree of ministerial autonomy (or respected specialisation) but also expect to consult and be consulted by their ministerial colleagues. As individual ministers with compartmentalised responsibilities they enter a collective 'deal': they themselves look after their area of responsibility (and inform the collective of anything of major significance) and in exchange expect other ministers to take care of their areas (and equally inform the collective of anything significant). Hence, a functioning ministry is similar to a sporting team where each player is given specific responsibilities for a dedicated role or position, each may have to help out at stressful times, but each player performs a given role for the team (see Howard 2010, 234-8). It is their collective bargain, their collective exchange relations.

Moreover, Australian ministers are also appointed, individually and simultaneously, as members of a collective advisory committee to the Crownas members of the executive council and advisers to the Governor-General (similar to the UK Privy Council serving the Monarch). This latter appointment is constitutional and legal in form but largely symbolic in effect (and not the equivalent to cabinet), but nevertheless underscores the collegial conventions of executive government. Legal authority is exercised by the 'Governor-General-incouncil'. As a ministerial team there is some expectation of shared or bargained loyalty (often underscored by edicts from the prime minister at regular intervals). Under bargained loyalty, a particular minister invests and positively displays his/her loyalty to the ministerial group (or individual colleagues) and in exchange the other ministers give that particular minister their loyalty. It is a quid pro quo or a mutual insurance arrangement based on necessity, and it helps build an esprit de corps.

So, although ministers are not formally appointed as a collective, they seek to exist and operate as a collective entity, until circumstances demand some readjustment. This expression of collective responsibility (or cabinet solidarity) is a political convention rather than a constitutional requirement. Ministers in a sense form a joint commitment: individually they agree to defend each other in exchange for each of the others defending them when circumstances dictate. It is a mutual pact or protective bond. And, implicitly, they accept as part of this deal that they may be forced to tender their resignation for the collective good of the government if they are badly damaged or are unnecessarily damaging the government as a whole. One example is the vigorous defence by Prime Minister Paul Keating of his hapless Sports Minister, Ros Kelly, over the 'sports 
rorts' scandal (see below), where he publicly defended her to the hilt over some months until her resignation could no longer be averted, and she had to be 'culled to save the herd' (see Wanna et al. 2001, 146-9).

In Australia the notion of cabinet solidarity traditionally insisted that the 'cabinet as a whole is responsible for the advice and conduct of each of its members' and that 'cabinet should stand or fall together' (Quick and Garran 1901, 705). This is a longstanding interpretation and has regularly been codified in Cabinet Handbooks (Australian Government 1983-2009). In other words, cabinet, and predominantly the prime minister, is the primary and effective forum that controls and monitors the behaviour of ministers in real time, not the parliament; the legislature is but the final theatrical tribunal that exercises a partial prudential oversight (and usually post hoc). Moreover, it is the cabinet's responsibility, and again predominantly the prime minister's, to ensure collective solidarity is maintained. Yet the rigid imposition of these twin political doctrines (control over ministers and their solidarity as a group) has been difficult to maintain, and so various prime ministers have resorted to some creative interpretations to maintain the balance and accommodate dissent or breaches of collective responsibility (Weller 1984, 1985, 1990). Mavericks or serial dissenters in the ministry have often been permitted some latitude by prime ministers unwilling to risk public disunity-Kevin Rudd in Gillard's cabinet is a case in point.

Consequently, within the doctrine(s) of cabinet solidarity a range of interpretations exists, and each is open to the discretion of the prime minister in different circumstances.

- Hardline notions of the need for complete unanimity (and the avoidance of public criticism of one's colleagues) stemming from Lord Salisbury's edict on cabinet collective responsibility are often cited and paraded as 'hard rules' but, at best, these are normative aspirations and are difficult to impose especially over serious policy disputes.

- Prime ministers find it much harder to enforce the hardline Salisbury notion of solidarity in practice especially in relatively small parliaments (or tight parliaments); often they have to make concessions especially to powerful ministers or those with an influential powerbase.

- A more euphemistic Australian compromise, expressed by Quick and Garran (1901), is that cabinet 'should have one harmonious policy'; in other words, solidarity means avoiding outright public dissent by cabinet ministers (although it may be possible to challenge cabinet decisions in party forums such as parliamentary party meetings or party conferences).

- Confidentiality of cabinet deliberations is a crucial component of collective responsibility; cabinet's internal deliberations remain secret and its business 
is not leaked or canvassed in public; political or policy disagreements are meant to remain confidential; it is important not to divulge the particular policy stances or positions taken by other individual ministers or what they said on particular issues, especially those on the losing or opposing side.

- Confidentiality is an instrument of control for the prime minister and other senior ministers; it is also a test of loyalty of cabinet colleagues (not leaking, being trustworthy, being a confidential sounding-board, and so on).

- Increasingly, the conventions surrounding solidarity have been codified in Cabinet Handbooks and ministerial guides by prime ministers and their departments (often more by officials than the politicians); at times, these have had to be reworded to accommodate latitude, discretion and even exceptions to the 'rule'; although the most recent Cabinet Handbook (Australian Government 2009) presents the general principles as if they insist on absolute agreement and confidentiality (that is, no public dissent in the party room or outside to the general community); these codes pretend they do not countenance exemptions, but clearly political practice does.

Hence, while collective responsibility exists as a 'fundamental' convention (and as an aspirational ideal), it is couched in interpretation through many subordinate or 'lesser' sub-conventions that give it practical meaning. It changes in emphasis over time and according to different circumstances. For instance, while it is insisted with absolute conviction that cabinet ministers do not oppose government policy in public, some do and get away with it. In the Rudd Government, the Resources and Energy Minister, Martin Ferguson, made statements indicating he opposed the Labor Government's proposed Fuel Watch scheme on the grounds that it would increase petrol prices and hit lower-income families hardest. Ferguson's dissenting views were contained in written correspondence to his cabinet colleagues that was leaked after the decision was taken (so who leaked and why?). He ventured his defence to ABC Radio that 'as part of a Cabinet process, I am expected to actually express a view as the Minister of Resources and Energy...I made that contribution to the Cabinet processes, Cabinet decided that my views were not appropriate and Cabinet correctly decided to introduce a Fuel Watch scheme' (ABC News, 27 May 2008). His (leaked) correspondence and then his explanatory interview on air clearly demonstrated he opposed the decision, but he was saved by his subsequent comments reaffirming the principle of solidarity ('I am one who absolutely believes in the Cabinet process, and I accept my responsibility to argue out what is appropriate, but also to absolutely accept the outcome of Cabinet'). Ferguson was not considered to have personally leaked the letter, and the incident was covered up with a Department of the Prime Minister and Cabinet (PM\&C) investigation into the leak. 


\section{Balancing the Competing Logics of Individual and Collective Responsibility}

In any ministry the competing logics of individual and collective responsibility will coexist uneasily; they can operate harmoniously or in juxtaposition and on occasions collide. Arguably, the dynamics of individualism and collectivism are maintained in some sort of creative tension, but what keeps these forces in check? The following are important factors mediating these dynamics

- the political need to create the perception of collective solidarity, to appear unified and politically coherent, to be perceived to be in control of their agenda; to avoid embarrassing inconsistencies or incoherence

- leadership styles and behaviours that meld the ministry; the necessary leadership qualities to find ways to embrace the cabinet or ministry and value the input of colleagues into political or administrative decisions; strategically managing the collective

- the need to have clear lines of political demarcation over matters likely to come before the government; a clarity of roles and responsibilities within the ministry; ministers may operate with some autonomy in their own domains and be expected to take charge of a set of responsibilities yet still be required to explain their priorities to their colleagues and persuade them of their merit

- the importance of internal hierarchical principles of ranking and predictable patterns of promotion; ministerial or party seniority, known pecking orders, entitlements to office or tenure, the notion of internal queues for positions, esteem and personal standing; some collegial acceptance of the order of 'standing' (the issue here is: who is really important, who has to be treated differently, who can be discarded, and so on)

- the need to accommodate factional groups or make cross-party accommodations (including coalitional politics)

- the continual assessment of risk and the fear of a scandal or 'stuff-up'; the potential threat of individual dismissal or demotion as ministers; the likelihood of enforced resignation; or being assigned unpleasant or difficult responsibilities

- the impact of the media and public commentary on ministerial performance, and the representation of the government's 'stocks' to the wider public

- the fear of disunity and loss of public support for the government; opinion poll reactions; the comparative polling position of their political rivals: the opposition. 
These factors are continually in tension and are regularly reconfigured as the government remains in power and perhaps loses momentum, records successes or weathers failures, hits crises or scandals, and either loses key personnel or gains replacements.

\section{The Ministry as a 'Buckle' between the Leader and the Party}

Cabinet is a constitutional body not mentioned in the Australian Constitution (or by most of the States, perhaps following the Bagehotian notion of cabinet as the 'efficient secret' of the English Constitution). Cabinet is the epicentre of executive government and public policy. It is also an ever-changing institution, run according to evolving practices and conventions that suit the prime minister of the day. In most Westminster systems, it is 'essentially an informal body; it is unsuited to formal statement in a Constitution. Practices as to its composition and operation can and do change from one government to the next; it is even possible that some system other than the present one of a "cabinet" might evolve' (Constitutional Commission 1987, 15). Yet cabinet has survived, and been continually remade. Its disciplines are sometimes tightened or relaxed, its rules made more or less informal, and some prime ministers set more store by it than others; but it continues to serve a range of useful and even indispensable political purposes for the prime minister and the government as a whole. It can be argued that the main reason for cabinet's survival is not that it has remained static, but that as an institution it has evolved and changed as the political system itself has evolved. Cabinet recalibrates itself.

Famously, Walter Bagehot once saw cabinet as the 'buckle' between the legislature and executive government. He was at the time wrestling with the (erroneous) continental European notion of the 'separation of powers' doctrine (executive policy making, legislative law making and judicial independence), promulgated by Montesquieu, against which Bagehot was arguing its empirical limitations in Westminster. He was also writing in an era before the arrival of mass-based, disciplined, adversarial political parties, which changed many of the norms and conventions of parliamentary politics.

Today, if cabinet remains an institution useful to modern party parliamentary democracies it may not be because it performs this traditional Bagehotian 'buckle'. The overlap of personnel between the executive and the legislature (the ministry which sits in parliament) no longer constitutes the cabinet's primary function or the reason for its longevity. Cabinet performs a much more important 'buckle', combining the party leader with his or her senior colleagues and with the wider party room (or caucus). Cabinet is now the buckle between 
the party leader (or core leadership group) and the party backbench. And, as this 'party buckle', it fulfils many important functions: it allows a confidential arena for frank discussion and deliberation; it politically hones the government's strategy; it serves as an information exchange for open debate; it arbitrates between protagonists or different policy options; it coordinates across parts of government; it determines resource allocations; it steers the government through crises; and it serves as a 'watchdog' for problematical issues or idiosyncratic decisions not advantageous to the government (see Davis 1997, 48). But cabinet also serves other important political purposes for the collectivity over time: it is the incubator of up-and-coming talent in the ministry and is useful in spotting emergent talent in the party room (the process of renewal); it functions as a sounding-board for alternative ideas or criticisms out of the public gaze; it can function as a court of appeal for those who have lost in the decisionmaking process (leaders, senior and junior ministers); it can act as a review body or provide a second opinion about decisions already taken (as a safetyvalve function). In these important ways, the cabinet acts as a bridge between the leader and the party - operating through the 'soft' skills of communicating, persuading, listening, advising, endorsing, scoping, warning, and so on.

Party leaders and their cabinet colleagues first and foremost have to maintain the confidence of their own party. Any prime minister has to maintain the confidence of his/her cabinet and ministerial colleagues, and also the backbench and party room. Over the period 2005-07, John Howard was losing the confidence of his cabinet and party room (and famously initiated an internal review of the support for his leadership in July 2007), but he did not lose numerical support and his principal opponent, Peter Costello, never acquired the numbers to challenge and defeat him (see Howard 2010, 622-5). During Howard's last two terms (200107), the Liberal party room consisted of about 106-7 members and senators, of whom about 80 per cent remained loyal Howard supporters while only 20 per cent backed Costello, and this breakdown did not shift greatly over the entire life of the government. By contrast, when Kevin Rudd spectacularly lost the confidence of the Labor caucus in mid-2010 he was deposed in an overnight coup led by three or four backbench 'faceless factional leaders' who had no public visibility. Not only was Rudd challenged by the left's Julia Gillard, on whose behalf the factional leaders were accumulating the numbers for a spill, but his own numbers evaporated to the extent that he did not even contest his removal from office (Aulich and Evans 2010). At the end, it was reported that Rudd had the support of two or three cabinet ministers and a handful of loyal backbenchers out of a caucus of 107. The extraordinary deposition of a firstterm prime minister by the Labor caucus was largely attributed to his inability to operate and lead as a team player (Aulich and Evans 2010). 
Individual ministers themselves primarily have to maintain the confidence of the prime minister, and to a lesser extent the confidence of their other cabinet colleagues. The party backbench may express occasional internal criticisms, but is generally far less important in determining the fate of individual ministers. At various times, the retention of the confidence of the prime minister in a particular minister or the prime minister's political support in trying times is critical to the overall solidarity of the government. This is particularly important when individual ministers come under attack or are accident-prone, where the leader has to weigh up the politics of defending the minister out of collegiality or cutting the minister loose to protect the standing of the rest. Often the prime minister makes an assessment of the fate of the offending minister in terms of the seriousness of the scandal and the ways in which the minister concerned attempts to explain or defend themself in its wake.

\section{Public Expressions of Togetherness: Creating the image or brand}

Over time, in any ministry, the exercise of collective solidarity may be active or passive, genuine, cosmetic or even mythical (Dell 1980), but it is probably more important to recognise that it is usually imperative for the government to maintain the impression of collegiality and coherence - the pretence that they can work effectively as a team. To survive as a government, ministries must show they can maintain the confidence of the house, put up a credible front to their political opponents and the media, and as a working ministry find ways to deal with the business of state, much of which will involve making collective decisions and imposing collegial executive authority.

Hence, governments feel the need to invest in the impression of togetherness. In advertising parlance, ministries operate as branding devices around a leader and leadership group. They help create the image of corporate government. Collective solidarity is important in image construction and image control, as marketing strategies to convey the impression that the government remains in control of the political agenda and is effective in the dissemination of political messages. Collective solidarity is also a defensive tactic when governments need to engage in damage limitation. Accordingly, much time and effort are expended giving the impression that ministries are collective and cohesive entities (from ministerial lists and group photos at the swearing in to expressions of group solidarity in the media and parliament, the representation of each other in other chambers and refraining from speaking publicly on matters relating to another minister's portfolio). 
Today, unity and cohesion are important not merely to announce and support decisions unanimously (the traditional rationale for collective responsibility), but to enable the government to operate proactively. Acting in concert reinforces the (positive) impression that the government possesses a narrative or coherent agenda, appears 'on message' in the 24/7 media cauldron, demonstrates information control and the coordination of 'spin', is coordinated in the timing and staging of public announcements, and is proficient in the tactics of whom to protect (their own besieged ministers) or whom to target for attack (shadow ministers or outside critics). Cohesion, coordination and coaching are indispensable collective strategies in the government's arsenal of weapons.

But there is a crucial asymmetry in operation in the standing of the brand. Individual ministers generally can do little to enhance the brand image (perhaps through achieving exceptional 'successes' or personal association with a popular policy), but they can easily damage the party brand or harm the particular leader's standing. Within collective responsibility individual ministerial competence is unremarkable and un-newsworthy; ministerial incompetence or scandalous behaviour achieves notoriety and saturation coverage. The brand is only as strong as its weakest link, and so over time ministers inevitably become liabilities, and when necessary are removed or demoted by the astute prime minister.

\section{Imposing Internal Discipline: How far are ministries cohesive?}

\section{Leadership Style: When to crack the whip}

Prime ministers insist on internal discipline. To them, enforcing control is the most important aspect of collective responsibility. Discipline can be enhanced (or eroded) by prime ministerial style in 'working with cabinet' and compositional factors of who comprises the ministry. As Weller has argued, the exercise of discipline by the prime minister is a 'matter of political calculation and convenience, not some immutable physical principle' $(2007,207)$. Thus, both Jack Curtin and Ben Chifley struggled to discipline the renegade Eddie Ward despite the fact he was a serving cabinet minister. On big issues, Ward, along with a future leader Arthur Calwell, would seek to appeal to caucus to circumvent or defeat cabinet decisions (Weller 2007, 79-83). Malcolm Fraser, anxious to restore some order to the cabinet process, once argued that cabinet needed to be a 'tight ship' based on 'contest-and-control', where debate could 
be lively one minute but where ultimately authority had to be imposed. He told the academic Graham Little, who was undertaking a 'psycho-social' study of his administration:

I think there might be a difference between being a hard task-master and running a tight ship, but there is no doubt that there has got to be discipline in a team. People have got to be able to express their views strongly...they're no use if they don't. But then once a decision is made, that's got to be it for all of us. Whoever is on the winning, or whoever is on the losing side, has to accept the decision as it comes out. (Little $1989,15)$

Fraser in some instances cut some of his ministers very little slack when they disgraced themselves (for example, the sacking of Glenn Sheil in 1977 or Reg Withers in 1978), but extended considerable latitude to others including Peter Nixon, Ian Sinclair, Jim Killen and John Howard, often to the exasperation of his own party (see Hughes 1992, 141).

Bob Hawke wanted to insist on tight cabinet discipline (and codified his expectations publicly in an extensive Cabinet Handbook) but was tolerant of occasional dissidents (such as Stewart West), and sometimes cabinet/caucus revolts (such as over the reversal of the MX missile commitment he had reaffirmed to the US President in 1985). His successor, Paul Keating, was less interested in codified manuals, but insisted cabinet solidarity was the 'essence of our system' (Blewett 1999, 32). He went to extraordinary lengths to defend his ministers, even when their fate looked sealed. Keating adopted a political calculus of what would cause least harm to the collective. He defended the embattled Treasurer, John Dawkins, when he struck trouble over his 1993-94 budget; then he went to great lengths to protect his lightweight Sports Minister, Ros Kelly, during 1993-94 after she had presided over a funding rort to award sports facilities disproportionately to marginal Labor electorates. He refused to allow her to appear before a senate inquiry investigating the scandal, while asserting she had done nothing wrong. He was eventually forced to allow her to appear before a house committee where she effectively hanged herself by her own naive admissions that she had concocted the sports funding schemes on a whiteboard without defensible criteria. Keating, however, was far less motivated to defend his Industry Minister, Alan Griffiths, over the 'sandwich shop affair' when it appeared he had used his office (and perhaps ALP funds) to subsidise a failed local firm that was owned by a business partner of Griffiths.

John Howard talked long and hard before becoming prime minister of the need for ministerial accountability, and issued a fairly tough Ministerial Code of Conduct 
on assuming office in March 1996. Unfortunately, his ministerial colleagues (many of whom had compromising business interests or were determined to exploit their expense accounts) were not on the same wavelength. In Howard's first term, eight ministers were forced to resign, mostly over relatively minor indiscretions, expense account irregularities and a lack of documentation for expenses claimed (only one minister was forced to resign over poor performance in his first term, Senator Amanda Vanstone). ${ }^{3}$ Howard responded by relaxing his code of conduct on pecuniary interests and instructing the Department of Finance to take over the processing of ministerial expense claims to ensure due compliance. He also did not insist that the Industry Minister, John Moore, resign after he continued to manage his share portfolio, including shares in industrial firms, well after he had become minister. After his expedient relaxation of the rules, Howard lost no more ministers to personal indiscretions until March 2007 when two went in short succession: the Human Services Minister, Senator Ian Campbell, who was compromised after dealing with disgraced former WA Premier Brian Burke, and the hapless Minister for Ageing, Senator Santo Santoro, who embroiled himself in a conflict-of-interest scandal involving medical firms and was accused of neglecting to register his current pecuniary interests. A succession of other Howard ministers resigned mid-term or at a time of their own choosing not because of a scandal (for example, Tim Fischer, Jocelyn Newman, John Moore, Richard Alston, John Anderson, Robert Hill, Amanda Vanstone and Rod Kemp) and others called it a day around election times (John Fahey, Peter Reith, Michael Wooldridge, Daryl Williams and David Kemp).

Kevin Rudd did not overly trust his cabinet colleagues and increasingly resorted to a kitchen cabinet of four senior ministers to decide most significant decisions (the so-called 'gang of four' — namely: Rudd, his deputy, Julia Gillard, Treasurer, Wayne Swan, and Finance Minister, Lindsay Tanner-who were all on the Strategic Budget Priorities Committee of cabinet). His penchant for what he regarded as 'efficient decision-making' led him to alienate his colleagues, who reputedly could turn up to cabinet meetings only to find predetermined decisions listed in papers tabled at the commencement of the meeting (see Tingle 2010; Wanna 2010). His cabinet was not particularly undisciplined, but Rudd's treatment of its members certainly fed into their resentment of him and his style, which eventually led to his downfall.

\footnotetext{
3 Amanda Vanstone was a 'wet' cabinet minister in the first Howard term, but was demoted to the outer ministry in the second term for not getting on with her department and for not making policy progress on the Liberal agendas. She re-exerted herself as Justice Minister and was reinstalled into cabinet in the third term. Kevin Rudd similarly demoted Peter Garrett (a non-aligned minister) after the 'pink batts' affair-but chose to retain him in cabinet, probably because the Prime Minister had pushed for the program despite some warnings from the minister/department.
} 


\section{Party and Factional Dynamics: Tension or stability?}

In Coalition governments, relations between the two 'coalesced' parties are complex and occasionally fraught, with some deep-seated animosities and policy differences apparent. The Nationals' preference for regional expenditures, agricultural subsidies, family farms and opposition to issues such as deregulation and water reform have often propelled them into serious conflicts with their larger partners, the Liberal Party. The Nationals' traditional control of certain portfolios (agriculture, infrastructure, trade) often allows them to impose their priorities in these areas of strategic significance to their constituency (Botterill and Cockfield 2009). This arrangement makes it harder for the Liberals to initiate sectoral reforms (for example, the single-desk wheat-marketing arrangements). Personal cross-party allegiances can overcome some of these tensions-as occurred in Malcolm Fraser's cabinets with his close reliance on the leading Nationals (Doug Anthony, Peter Nixon and Ian Sinclair). John Howard did not have the same close personal friendships with his senior Nationals (Tim Fischer, John Anderson and Mark Vaile) but maintained a respect for their abilities. This did not prevent him from decreasing the representation of Nationals in cabinet from four in his first two cabinets (1996-2001), compared with 14 Liberals, to just three in his last two terms (2001-07) with 15 Liberals. The reduction in the Nationals' representation in cabinet was due to their declining parliamentary representation (and also because senior Liberals doubted whether the Nationals had any serious ministerial talent available).

Unlike in Labor governments, in Coalition ministries factional alliances are not as pronounced. Left-right alignments are found in centre-right cabinets but are not usually the basis of political disputes or policy differences. In a rough estimation of factional groupings, Howard's first cabinet had nine 'dries' to nine 'wets' (this 'balancing' had been a precondition of Howard's second run at the opposition leadership in 1995) and finished with 11 'dries' to seven 'wets' (although some of the original 'wets' had by then become hard 'dries'). Other internal groupings are usually aligned around personal identifications with leaders or contenders. In Howard's ministries the Costello supporters increasingly became frustrated and occasionally vocal but never managed to wrest the numbers from Howard's camp. In opposition after 2007, the leadership preferences of these two former solid blocs became problematic. The Liberal leadership was initially decided in a narrow contest between Brendan Nelson's supporters (ex-Howardites and anti-Turnbull critics) and Malcolm Turnbull's numbers; then, following internal disquiet about Nelson's own performance, Nelson was narrowly defeated by Turnbull in 2008; after which mounting right-wing opposition to Turnbull's leadership led to a three-way contest between Turnbull, Joe Hockey and Tony Abbott. Although Hockey had been expected to defeat Turnbull easily, he alienated many supporters by softening his approach to climate change and 
came third in the ballot; his votes then drifted to Abbott who beat Turnbull by one vote in November 2009. The leadership issue did not subside until Abbott cemented his position after his near-victory at the 2010 election.

The factional composition of the ministry and the power-base of crucial individual ministers are more important among Labor governments and can affect the coherence and internal discipline of cabinet. Discipline was arguably more difficult when caucus elected the entire composition of ministries and the leader had limited ability to determine who was in his team. Chifley, Whitlam and Hawke felt uncomfortable with some of their 'caucus-elected' ministers and would have excluded or demoted them if it had been within their discretionary powers. Since 2007 both Rudd and Gillard have exercised the right to select their own ministries (in consultation with factional leaders but with greater personal choice from the leader). Federal Labor governments have long been bifurcated between the right and left factional blocs, but with ministers largely selected on seniority and their colleagues' assessments of their abilities, with some rewarded on factional alignment or in return for dastardly deeds over, say, a leadership challenge.

Since the mid-1980s factional 'balance' in Labor governments has produced greater degrees of stability, consistency and predictability. Hawke was given a talented cabinet dominated by MPs from the right and centre-left factions, many of whom had outstanding abilities. Keating's cabinets were dominated by his own NSW right faction (with weaker performers from right factions in other States), but he also accommodated the left who provided his deputy (at the expense of the fading centre-left). Exercising greater personal choice (but also dependent on the left's numbers to secure his own elevation), Kevin Rudd's sole cabinet was the most left-aligned in Labor's history, although the representation of the right and left was relatively equal. Two members of his 'gang of four' were from the right (himself and Swan, who sometimes had tetchy relations) and two from the left (Gillard and Tanner). The factional composition of Labor's cabinets since the early 1980 s is shown in Table 2.1 .

Table 2.1 The Factional Composition of Four Labor Cabinets, 1980s-2010

\begin{tabular}{|c|c|c|c|c|}
\hline $\begin{array}{l}\text { Factional } \\
\text { grouping }\end{array}$ & $\begin{array}{c}\text { Hawke Govt } \\
\text { 1980s } \\
\text { (18 members) }\end{array}$ & $\begin{array}{c}\text { Keating Govt } \\
1993 \\
\text { (19 members) }\end{array}$ & $\begin{array}{c}\text { Rudd Govt } \\
2009-10 \\
\text { (18 members) }\end{array}$ & $\begin{array}{c}\text { Gillard Govt } \\
2010 \\
\text { (20 members) }\end{array}$ \\
\hline Right Factions & 8 & $13(11)$ & 8 & 11 \\
\hline $\begin{array}{l}\text { Centre-left or } \\
\text { unaligned }\end{array}$ & 8 & 3 & 1 & 1 \\
\hline Left factions & 2 & $3(5)$ & 9 & 8 \\
\hline
\end{tabular}

Note: The drop in the right's factional numbers in the Keating cabinet was due to ministers from the right resigning and being replaced with ministers from the left. 


\section{Containing the Politics of Cabinet}

Today's cabinets meet far less frequently than cabinets of yesteryear. In an era of less ideological polarisation, the fact that cabinet meets less frequently means that there is less chance of or opportunity for ministerial dissent. Cabinet can become more akin to a briefing forum, mulling through political strategies and acting as a cheer squad for the government as a whole. Weller (2007) reports that cabinets in the 1930s and 1940s met anything up to 90 times a year; by the 1950s-1970s, the number of meetings had stabilised at about 40 to 65 meetings a year with many other associated cabinet committee meetings; by the time of the Fraser Government, cabinet was meeting more than 160 times a year (more than 400 if cabinet committees were included), often with separate meetings of cabinet ministers held in quick succession. Hawke brought the pattern of cabinet meetings back to about one a week (fluctuating between 41 and 63 a year); but Howard reduced both the regularity of meetings and the business needing to be discussed (through the 10-day rule), bringing full cabinet meetings down to as low as 35 per annum (but he hived off National Security Committee meetings). Rudd did not greatly increase the regularity of meetings but invested more confidence in cabinet committees than had Howard.

\section{Disciplining Cabinet through Orderly Retirement and Refreshment}

Cabinets rely on refreshment and replacement but individual ministers may be reluctant to retire or move on unless induced to do so. Prime ministers in long-serving governments have invested some time orchestrating the orderly retirement of tired or non-performing ministers, not necessarily because they have disgraced themselves in some scandal. These regular, orderly retirements are colloquially referred to as 'taps on the shoulder'. Robert Menzies, using cricket metaphors, would say to dullard ministers who had been in parliament or in the ministry for far less time than he had that their 'innings was over' - they were sent back to the pavilion. In Keating's second ministry, John Dawkins and Brian Howe both retired to clear the way for their successors. Of the 15 cabinet members of the first Howard ministry, eight retired of their own accord without being forced out or sacked (Fischer, Anderson, Reith, Fahey, Wooldridge, Alston, Newman and Hill). But Howard gradually adopted a principle of ministerial rotation and refreshment over the downtime of the summer recess. Each year he would take a few weeks' break, using the time to consider the relative strengths of his ministry and configure his 'Christmas list' while watching cricket. On resuming official duties in late January, he would announce some resignations from his existing ministry and indicate his chosen replacements. This was a repeated and almost formalised renewal strategy undertaken in most Januaries 
from his second term - in 2001 four cabinet ministers and seven outer-ministers were moved; in 2002 one outer-minister; in 2006 four moves occurred in cabinet and 11 in the outer-ministry; and in 2007 three cabinet changes were made and six in the outer-ministry. All these movements occurred in January alone.

Only one minister in Kevin Rudd's ministry had to resign over a scandal (the Defence Minister, Joel Fitzgibbon, in June 2009). But in Labor's first term a number of ministers indicated they were retiring of their own accord including: John Faulkner, Bob McMullan, Bob Debus and Lindsay Tanner; and from the Gillard ministry it is likely Nick Sherry, Simon Crean, Jenny Macklin, Warren Snowden, Martin Ferguson, Robert McClelland and possibly Kevin Rudd will call it a day soon.

\section{Conclusion}

It is easy to observe that collective ministerial responsibility is a fallacy or myth from a single vantage point in history, especially when a particular government is at the time in terminal decay or wracked by successive ministerial resignations. It is much harder to draw such conclusions when one takes a longer view of parliamentary systems and government regimes. Governments new and old continually and repeatedly seek to create collective responsibility and enforce its observance to the extent they are capable. Ministerial solidarity is a recurring aspiration of governments in which they invest considerable political capital, even in its more euphemistic forms of collective purpose or collective tolerance. It is one of their principal anchors in a sea of uncertainty.

If collective responsibility is not always perfect or maximally effective, perhaps as observers we are too exacting in our standards and judgments. After all, we are observing the interactions and relations between groups of political actors (collegial rivals) in a constantly changing political context (exploited by the media and opponents), in circumstances that cannot be controlled, when routinely the business of government still has to proceed. Hence, above all else, collective responsibility is not an immutable principle (even if it can be expressed thus in codified ministerial guides) but an expedient convention enforced to greater or lesser degree by the prime minister, who has to weigh competing options and consequences. In this sense, collective responsibility as a form of accountability is less oriented externally towards parliament but more importantly internally oriented towards the leader and other senior ministers. Analytically, it may be better to think of collective responsibility as a way of ministers controlling themselves as ministers. Finally, it may be that collective responsibility is like a dog dancing on its hind legs: what is remarkable is not that it is done well, but that it is done at all. 


\section{References}

Aulich, C. and M. Evans. 2010. The Rudd Government. Canberra: ANU E Press.

Australian Government. (various editions 1983-2009). Cabinet Handbook. Canberra: Department of the Prime Minister and Cabinet.

Blewett, N. 1999. A Cabinet Diary: A Personal Record of the First Keating Government, 1991-93. Adelaide: Wakefield Press.

Blewett, N. 2006. 'The Personal Writings of Politicians'. In Australian Political Lives: Chronicling Political Careers and Administrative Histories, eds T. Arklay, J. Nethercote and J. Wanna. Canberra: ANU E Press.

Botterill, L. and G. Cockfield. 2009. The National Party. Sydney: Allen \& Unwin.

Codd, M. 1990. 'Cabinet Operations of the Australian Government'. In The Cabinet and Budget Processes, eds B. Galligan, J. Nethercote and C. Walsh. Canberra: Centre for Research on Federal Financial Relations, Australian National University.

Constitutional Commission. 1987. Executive Government. Report of Advisory Committee to the Constitutional Commission. Canberra: Commonwealth of Australia.

Crisp, L. F. 1973. Australian National Government. Third edition. Melbourne: Longman.

Davis, G. 1992. 'Prime Ministers and Parties'. In Menzies to Keating: The Development of the Australian Prime Ministership, ed. P. Weller. Melbourne: Melbourne University Press.

Davis, G. 1997. 'Executive Government: Cabinet and the Prime Minister'. In Government, Politics, Power and Policy in Australia, eds D. Woodward, A. Parkin and J. Summers. Sixth edition. Melbourne: Longman Cheshire.

Dell. E. 1980. 'Collective Responsibility: Fact, Fiction or Façade'. In Policy and Practice: The Experience of Government. London: RIPA.

Dicey, V. 1885 [1948]. Introduction to the Study of the Law and the Constitution. Ninth edition. London: Macmillan.

Dowding, K. and W. T. Kang. 1998. 'Ministerial Resignations 1945-97'. Public Administration 76(3): 411-29.

Encel, S. 1962. Cabinet Government in Australia. Melbourne: Melbourne University Press. 
Finn, P. 1990. 'Myths of Australian Public Administration'. In Public Administration in Australia: A Watershed, ed. J. Power. Sydney: Hale \& Iremonger.

Galligan, B., J. Nethercote and C. Walsh (eds). 1990. The Cabinet and Budget Processes. Canberra: Centre for Research on Federal Financial Relations, Australian National University.

Howard, J. 2010. Lazarus Rising: A Personal and Political Autobiography. Sydney: HarperCollins.

Hughes, C. A. 1992. 'Prime Ministers and the Electorate'. In Menzies to Keating: The Development of the Australian Prime Ministership, ed. P. Weller. Melbourne: Melbourne University Press.

Jennings, I. 1959. Cabinet Government. Third edition. Oxford: Blackwell.

Little, G. 1989. Speaking for Myself. Melbourne: McPhee Gribble.

Quick, J. and R. Garran. 1901. An Annotated Constitution of the Australian Commonwealth. Sydney: Law Books.

Sartori, G. 1976. Party and Party Systems. Cambridge: Cambridge University Press.

Tingle, L. 2010. 'Tensions Escalate Over Rudd's Kitchen Cabinet'. Australian Financial Review, 7 March.

Wanna, J. 2010. 'Political Chronicles: Commonwealth of Australia January to June 2010'. Australian Journal of Politics and History 56(4): 631-81.

Wanna, J., C. Ryan and C. Ng. 2001. From Accounting to Accountability. Sydney: Allen \& Unwin.

Weller, P. 1985. 'The Hawke Cabinet: Collective or Responsible?'. Australian Quarterly 57(4): 319-32.

Weller, P. 1989. Malcolm Fraser PM: A Study of Prime Ministerial Power in Australia. Melbourne: Penguin.

Weller, P. 1990. 'Cabinet'. In Hawke and Public Policy, eds C. Jennett and R. Stewart. Melbourne: Macmillan.

Weller, P. 2007. Cabinet Government in Australia 1901-2006. Sydney: UNSW Press.

Woodhouse, D. 1994. Ministers and Parliament: Accountability in Theory and Practice. Oxford: Clarendon Press. 